Zeszyty Naukowe Szkoły Głównej Gospodarstwa Wiejskiego w Warszawie Problemy Rolnictwa Światowego tom 17 (XXXII), zeszyt 3, 2017: 71-80

DOI: 10.22630/PRS.2017.17.3.54

Wiesław Dzwonkowski ${ }^{1}$

Instytut Ekonomiki Rolnictwa i Gospodarki Żywnościowej - Państwowy

Instytut Badawczy w Warszawie

\title{
Ewolucja produkcji ziemniaków w Polsce i UE
}

\section{Evolution of Potato Production in Poland and the EU}

\begin{abstract}
Synopsis. Produkcja i rynek ziemniaków w Polsce, Europie i na świecie podlega procesom ewolucji. Zmiany te w naszym kraju w ostatnich kilkunastu latach miały bardzo dynamiczny przebieg, zwłaszcza po akcesji Polski do UE. Zmianom podlega również produkcja ziemniaków i w innych krajach UE, ale mają one zdecydowanie łagodniejszy przebieg. W artykule podjęto próbę oceny tych zjawisk w Polsce i w innych krajach, kluczowych dla uprawy ziemniaków w UE. Wykorzystano do tego celu dane statystyczne Eurostat, statystki krajowe poszczególnych państw oraz informacje i materiały Komisji Europejskiej. W artykule skoncentrowano się na analizie zmian areału uprawy, wysokości plonów i zbiorów ziemniaków oraz ocenie procesów koncentracji. Wskazano na ich przyczyny, z których najważniejsze to zmiany zapotrzebowania rynkowego na ziemniaki.
\end{abstract}

Słowa kluczowe: ziemniaki, produkcja, ewolucja, Polska, UE

\begin{abstract}
The production and the market for potatoes in Poland, in Europe and in the world has undergone a process of evolution. The changes in Poland in the last decade or more have been very dynamic, especially after Poland joined the EU. The production of potatoes has also undergone changes in other EU countries, but they have taken a much milder course. The article attempts to evaluate the changes in Poland and in other countries that are crucial to potato production in the EU. Statistics from Eurostat, national statistics from individual states and information and materials of the European Commission were used in this research. The article concentrates on analysis of changes in production area, yields and potato harvests and evaluates the processes in chosen EU countries. Reasons for changes are discussed, most especially the changes in demand on the potato market demand.
\end{abstract}

Key words: potatoes, production, Poland, EU

\section{Wstęp}

Ziemniaki, obok pszenicy i ryżu, są najpopularniejszym źródłem pożywienia ludności świata. Uprawia się je na wszystkich kontynentach, najwięcej w Azji i w Europie. Na te dwa kontynenty przypada ponad 80\% światowego areału uprawy ziemniaków, przy czym ich produkcja jest ograniczana w Europie, a zwiększa się w Azji. Od ponad 10 lat Europa przestała dominować w produkcji ziemniaków, a największe zbiory odnotowuje się obecnie na kontynencie azjatyckim (Dzwonkowski i in., 2016). Z danych FAO wynika, że w ostatnich latach powierzchnia uprawy ziemniaków w Azji stanowiła już ok. 48\% światowego areału, a w Europie niepełna 35\%.

Wprawdzie ziemniaki są powszechnie uznawane za „chłodną” uprawę pory roku, mogą być i są uprawiane we wszystkich krajach Europy, ale wiąże się to z koniecznością zapewnienia wystarczającej ilości wody w czasie wegetacji. Gospodarka wodna i poziom

${ }^{1}$ mgr, ul. Świętokrzyska 20, 00-002 Warszawa, e-mail: wieslaw.dzwonkowski@ierigz.waw.pl 
opadów są prawdopodobnie jednymi z najważniejszych czynników decydujących o produkcji i jakości ziemniaków. Czas sadzenia różni się znacznie w poszczególnych regionach i zależy nie tylko od miejscowych warunków klimatycznych, ale również od planowanego wykorzystania rynkowego (Commission of the European..., 2007).

W ramach UE można wyszczególnić charakterystyczne trzy grupy krajów. Pierwszą grupę stanowi 5 krajów Europy Północno-Zachodniej: Belgia, Francja, Holandia, Niemcy i Wielka Brytania. W 2016 r. na kraje te przypadało prawie 58\% zbiorów UE-28, podczas gdy 5-6 lat wcześniej było to jeszcze niewiele ponad 40\%. Tworzą one główny region obrotów międzynarodowych, będący dużym eksporterem netto. Region ten charakteryzuje się stabilizacją wielkości zbiorów ziemniaków, gdzie niewielki spadek powierzchni uprawy kompensowany jest wzrostem plonów.

Odmienne tendencje zachodzą w krajach Europy Środkowo-Wschodniej, spośród których największym producentem jest Polska. W krajach tych występuje długookresowy trend spadku powierzchni uprawy, częściowo rekompensowany wzrostem plonów. Przyczyną było przede wszystkim ograniczenie paszowego wykorzystania ziemniaków, a po wejściu tych krajów do UE nie bez znaczenia jest również presja konkurencyjna ze strony eksportu z krajów Europy Zachodniej (Dzwonkowski 2012).

Również silny spadek produkcji ziemniaków ma miejsce w krajach Europy Południowej, zwłaszcza w Hiszpanii i Portugalii, ale również we Włoszech i w Grecji. Kraje te należą do największych importerów netto ziemniaków, a ich import systematycznie rośnie. Jest to związane ze znacznym spadkiem konkurencyjności ziemniaków produkowanych w tym regionie wobec ziemniaków uprawianych w Europie Północno-Zachodniej. Brak tej konkurencyjności jest związany ze znacznie mniej korzystnymi warunkami dla uprawy ziemniaków, niższą skalą produkcji, dużo gorzej zorganizowanym rynkiem oraz szybko rosnącymi w ostatnich latach kosztami produkcji takimi jak: wzrost cen, głównie importowanych sadzeniaków, rosnące koszty energii, wzrost nakładów na nawodnienia oraz wzrost pozostałych kosztów (Infante, 2008).

Europejski rynek ziemniaków jadalnych charakteryzuje się znaczną specjalizacją (Rembeza, 1995). Pomiędzy poszczególnymi krajami dochodzi często do dwustronnych przepływów, uzupełniających się asortymentowo. Równocześnie w trakcie sezonu handlowego główne kierunki handlu podlegają istotnym zmianom. Główny kierunek handlu ziemniakami wczesnymi przebiega z południa na północ i w ramach UE dotyczy Grecji i Cypru, Hiszpanii i Włoch, a następnie Belgii i Francji. Od września zaczyna dominować eksport z krajów Europy północno-zachodniej w kierunku południowym, a główną rolę w eksporcie odgrywają : Francja, Niemcy, Holandia i Wlk. Brytania. Wzrost wymagań jakościowych oraz presja cenowa powodują, że stopniowo następuje proces pogłębiania się specjalizacji zarówno poszczególnych krajów, ale także mniejszych regionów - dotyczy to zwłaszcza ziemniaków wczesnych oraz z przeznaczeniem ma przetwory spożywcze (Rembeza, 2002). Duże obroty handlowe ziemniakami między krajami UE wynikają z różnic klimatycznych i różnych terminów zbioru (Dzwonkowski, 2002).

W opracowaniu podjęto próbę przedstawienia ewolucji produkcji ziemniaków w krajach UE mających kluczowe znaczenie dla unijnego i europejskiego segmentu tego rynku, w tym również w Polsce,. W analizie skoncentrowano się na zmianach areału uprawy, wysokości plonów i zbiorów latach 2000-2016, w kluczowych dla uprawy ziemniaków krajach UE. Na podstawie danych dotyczących wielkości areału uprawy oraz struktury gospodarstw zajmujących się uprawą ziemniaków dokonano oceny procesów koncentracji w 
poszczególnych krajach. Z powodu dostępności danych w analizie struktury gospodarstw ograniczono się do lat; 2005, 2007, 2010 i 2013.

W analizie porównawczej uwzględniono Polskę, kraje tzw. UE-5 (Niemcy, Francja, Holandia, Belgia i Wlk. Brytania) oraz Rumunię, która obok Polski jest najbardziej liczącym się unijnym producentem ziemniaków w regionie Europy Środkowo-wschodniej. Przeanalizowano również podstawowe czynniki po stronie popytowej będące głównym czynnikiem sprawczym ewolucji długookresowych zmian w produkcji ziemniaków w Polsce i w UE. W tym celu dokonano porównań podstawowych składników bilansu ziemniaków w Polsce i w Niemczech. Do analizy porównawczej z Polską wybrano Niemcy głównie z powodów merytorycznych (największy producent ziemniaków w UE, zbliżone warunki klimatyczne i glebowe uprawy), ale również z powodu dostępności danych (przynajmniej od 7-8 lat Eurostat nie publikuje bilansów ziemniaków poszczególnych krajów UE).

W tym celu korzystano z materiałów źródłowych i publikacji GUS, statystyk handlu zagranicznego CAAC (Centrum Analityczne Administracji Celnej) i MF (Ministerstwo Finansów) oraz dostępnych zagranicznych źródeł statystycznych, w tym głównie FAO, Eurostat, materiałów Komisji Europejskiej, ZMP (Zentrale Marktund Preisberichstelle $\mathrm{GmbH}$ ) oraz AMI (Agramarket Informations - Gesellschaft mbH). Wyniki zaprezentowano w formie tabelarycznej i graficznej. Do interpretacji badań zastosowano metodę analizy opisowej i porównawczej.

\section{Zmiany areału uprawy, plonów i zbiorów ziemniaków w wybranych krajach UE w latach 2000-2016}

W Polsce, podobnie jak i w zdecydowanej większości innych krajów UE, maleje w uprawie i w produkcji rolniczej znaczenie ziemniaków. W 2000 roku w krajach Unii Europejskiej (UE-15) powierzchnia ich uprawy wynosił około 1,35 mln ha, a w 2016 roku było to niespełna 1,1 mln ha (Eurostat, 2017). W Polsce skala spadku była znacząco większa. Areał uprawy ziemniaków obniżył się z 1,25 mln ha w 2000 roku do około 0,31 mln ha w ostatnich kilku latach (Wyniki produkcji roślinnej, 2017).

Spośród wiodących producentów ziemniaków w UE wzrost areału ich uprawy miał miejsce jedynie w Belgii i Francji (rys. 1). W Belgii powierzchnia uprawianych ziemniaków zwiększyła się z 65,8 tys. ha w 2000 r. do 89,1 tys. ha w ostatnim roku analizowanego okresu, tj. o $35,4 \%$, przy średniorocznym tempie wzrostu na poziomie $1,9 \%$. Wzrost ten związany był $\mathrm{z}$ bardzo dynamicznie rozwijającą się produkcją przetworów ziemniaczanych $\mathrm{w}$ tym kraju, a zwłaszcza frytek. Belgia jest najmniejszym producentem ziemniaków spośród tzw. krajów UE-5, mających kluczowe znaczenie dla europejskiego rynku, ale jednocześnie największym producentem przetworów ziemniaczanych. Według ocen Potato Market (2017) 4,4 mln ton ziemniaków w 2016 r. zostało zużytych w przetwórstwie spożywczym (przy produkcji krajowej na poziomie 3,4 mln ton).

We Francji areał uprawianych ziemniaków w ostatnich szesnastu latach zwiększył się z 162,6 tys. ha do ponad 175 tys. ha, tj. niespełna 8\%. Wzrost ten wynikał z jednej strony ze zwiększającego się zapotrzebowania przemysłu przetwórczego, ale przede wszystkim z rosnącego eksportu ziemniaków do bezpośredniej konsumpcji, który w ostatnich latach wynosił prawie $2 \mathrm{mln}$ ton (Dzwonkowski, 2016). 


\section{W. Dzwonkowski}

W Niemczech powierzchnia uprawy ziemniaków w analizowanym okresie zmniejszyła się z ponad 304 tys. ha do 233,5 tys. ha (o 22,6\%), w Wlk. Brytanii z 166 do 139 tys. ha (o 16,3\%), a w Holandii z 180 do 156 tys. ha (o 13,3\%).

Największy spadek powierzchni, nienotowany w innych krajach, miał miejsce w Polsce, gdzie spadek sięgnął aż 75\% (z 1250 tys. ha w 2000 r. do 310 tys. ha w 2016 r., przy średniorocznym tempie spadku na poziomie 8,4\%). W niektórych krajach regionu (Węgry, Czechy, Słowacja) skala spadku była tylko nieznacznie mniejsza, ale kraje te mają niewielkie znaczenie dla europejskiego i unijnego rynku ziemniaków. Natomiast w Rumunii, która jest drugim obok Polski liczącym się producentem ziemniaków w tym regionie, areał ich uprawy zmniejszył się od 2000 r. o ponad $33 \%$, przy czym proces redukcji upraw nabrał przyspieszenia pod akcesji tego kraju do UE (2007 r.).

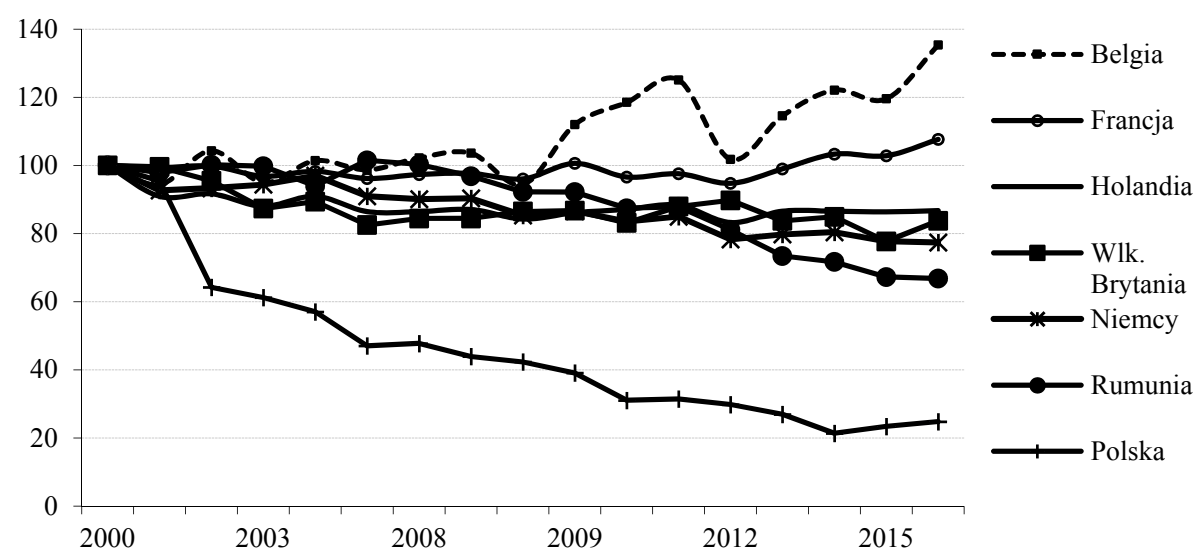

Rys. 1. Zmiany w powierzchni uprawy ziemniaków w wybranych krajach UE $(2000 \mathrm{r} .=100)$

Fig. 1. Changes area of potatoes in chosen EU countries

Źródło: opracowanie własne na podstawie danych Eurostat.

W krajach Europy Zachodniej spadek areału uprawy był częściowo rekompensowany wzrostem plonów, których poziom już na początku analizowanego okresu (2000 r.) był relatywnie wysoki i na przestrzeni ostatnich kilkunastu lat wzrósł zaledwie o kilka procent (Rys. 2). Ze względu na duże wahania plonów w poszczególnych latach, w zależności od warunków pogodowych w okresie wegetacji, do porównań zmian plonów wzięto średnie pięcioletnie na początku i na końcu badanego okresu. Z porównań tych wynika, ze średni poziom plonów ziemniaków w UE-5 zwiększył z 42,1 t/ha do 43,4 t/ha, tj. o niespełna 3\%. W tym okresie plony ziemniaków w Polsce wzrosły z 18,4 do 24,3 t/ha, tj. o 32,4\%. W poprzednich trzech dekadach dynamika wzrostu plonów ziemniaków w Polsce była dużo mniejsza. W Rumunii również miał miejsce wzrost średnich plonów ziemniaków (z 14,0 do $14,7 \mathrm{t} / \mathrm{ha}$ ), ale jego skala była zdecydowanie mniejsza niż w Polsce i wyniosła nieco ponad 5\%.

Konsekwencją ograniczania powierzchni uprawy był spadek zbiorów ziemniaków we wszystkich krajach UE, z wyjątkiem Belgii i Francji. W tych dwóch krajach zanotowano wzrost zarówno areału, jak i zbiorów. W Belgii produkcja ziemniaków wzrosła z 2,92 do 3,37 mln ton (o 15,4\%), a we Francji z 6,43 do 7,00 mln ton (o 8,8\%). 


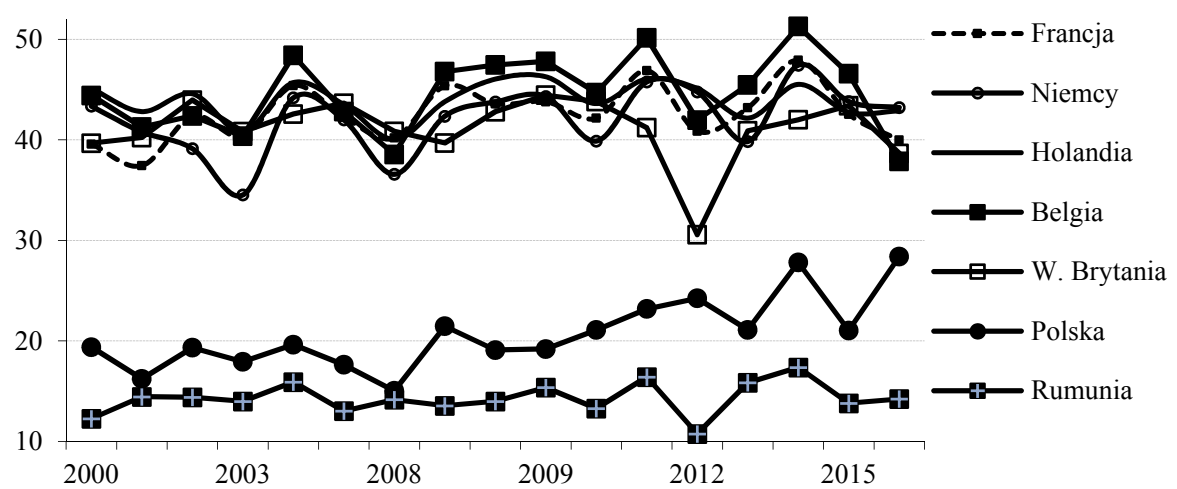

Rys.2. Plony ziemniaków w wybranych krajach UE ( $t /$ ha)

Fig. 2. Yields of potatoes in chosen EU countries ( $t / h a)$

Źródło: opracowanie własne na podstawie danych Eurostat.

W Polsce duży spadek areału przynajmniej w części zrekompensowany został znacznym wzrostem plonów (rys. 3). Produkcja ziemniaków w Polsce w 2016 r. wyniosła $8,80 \mathrm{mln}$ ton i była o $63,7 \%$ mniejsza niż w $2000 \mathrm{r}$. W Niemczech, które obecnie są w UE największym producentem ziemniaków, zbiory zmniejszyły się z 13,2 do 10,2 mln ton (o 23\%). W Holandii i Wielkiej Brytanii produkcja ziemniaków od 2000 r. obniżyła się o ok. $18 \%$, do 6,7 i $5,4 \mathrm{mln}$ ton.

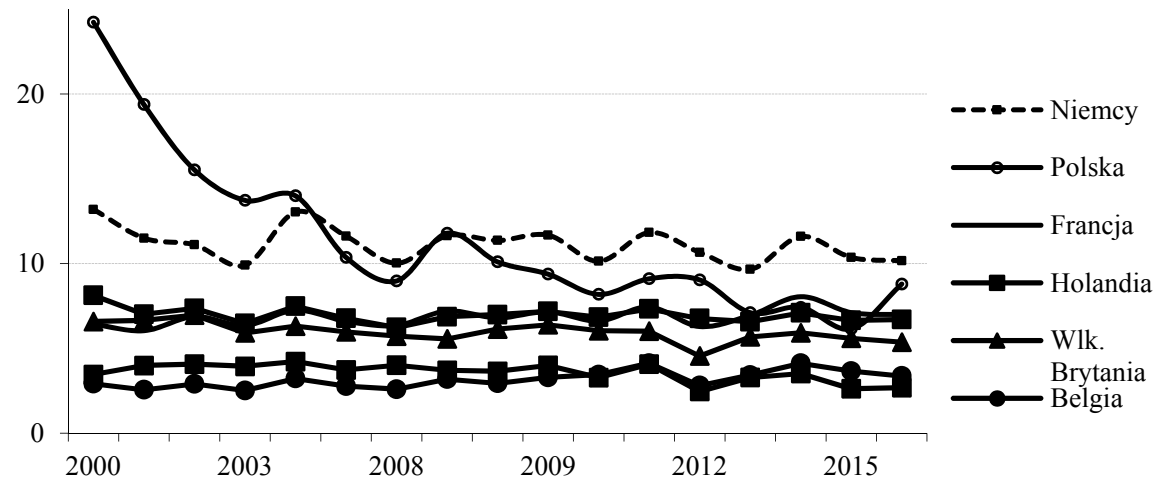

Rys. 3. Zbiory ziemniaków w wybranych krajach UE (mln ton)

Fig. 3. Crops of potatoes in chosen EU countries

Źródło: opracowanie własne na podstawie danych Eurostat

Zmianom areału uprawy, wysokości plonów i zbiorów towarzyszyły procesy zmian w strukturze obszarowej gospodarstw uprawiających ziemniaki w poszczególnych krajach UE. Jak wynika $\mathrm{z}$ danych i obliczeń zawartych w tabeli 1,we wszystkich analizowanych krajach znacząca spadła liczba producentów gospodarstw zajmujących się uprawą ziemniaków, również $\mathrm{w}$ tych krajach (Belgia, Francja), gdzie ich produkcja wzrosła $\mathrm{w}$ analizowanym okresie.

Spośród analizowanych krajów największą koncentracją uprawy ziemniaków charakteryzuje się Holandia, gdzie ich uprawą w 2013 r. zajmowało się 9160 rolników 
(10460 w 2005 r.), a średni ich areał przypadający na gospodarstwo wzrósł z 14,9 do 17,0 ha² w 2013 r. (tab. 1).Również dużą koncentracją produkcji ziemniaków charakteryzuje się Wlk. Brytania, gdzie uprawą ziemniaków w 2013 r. zajmowało się 8260 rolników (11280 w 2005 r.), a średni areał wynosił 16,9 ha (12,2 ha w 2005 r.) i był tylko nieznacznie niższy niż w Holandii.

Tabela 1. Powierzchnia uprawy i liczba producentów ziemniaków w wybranych krajach UE

Table 1. Area and number of potato producers in chosen EU countries

\begin{tabular}{|c|c|c|c|c|}
\hline Wyszczególnienie & 2005 & 2007 & 2010 & 2013 \\
\hline \multicolumn{5}{|c|}{ Powierzchnia uprawy (ha) } \\
\hline Niemcy & 276900 & 276600 & 254370 & 242790 \\
\hline Francja & 154630 & 154880 & 161150 & 166580 \\
\hline Holandia & 155780 & 157170 & 158270 & 155820 \\
\hline Belgia & 64950 & 67940 & 81760 & 73060 \\
\hline Wlk. Brytania & 137170 & 139930 & 138020 & 139650 \\
\hline Polska & 588180 & 549460 & 374760 & 337040 \\
\hline Rumunia & 250580 & 265180 & 118290 & 111450 \\
\hline \multicolumn{5}{|c|}{ Liczba producentów } \\
\hline Niemcy & 63920 & 55420 & 39950 & 33760 \\
\hline Francja & 27300 & 24130 & 28720 & 22730 \\
\hline Holandia & 10460 & 9770 & 9330 & 9160 \\
\hline Belgia & 12160 & 11570 & 11230 & 11270 \\
\hline Wlk. Brytania & 11280 & 11480 & 9130 & 8260 \\
\hline Polska & 1373820 & 1187260 & 663080 & 510250 \\
\hline Rumunia & 1122890 & 1068500 & 642330 & 714080 \\
\hline \multicolumn{5}{|c|}{ Średni areał uprawy ziemniaków (ha/gospodarstwo) } \\
\hline Niemcy & 4,33 & 4,99 & 6,37 & 7,19 \\
\hline Francja & 5,66 & 6,42 & 5,61 & 7,33 \\
\hline Holandia & 14,89 & 16,09 & 16,96 & 17,01 \\
\hline Belgia & 5,34 & 5,87 & 7,28 & 6,48 \\
\hline Wlk. Brytania & 12,16 & 12,19 & 15,12 & 16,91 \\
\hline Polska & 0,43 & 0,46 & 0,57 & 0,66 \\
\hline Rumunia & 0,22 & 0,25 & 0,18 & 0,16 \\
\hline
\end{tabular}

Źródło: http://ec.europa.eu/eurostat/data/database, dostęp 10.06.2017, obliczenia własne.

W Niemczech liczba producentów ziemniaków zmniejszyła się prawie o połowę z prawie 64 do 34 tys., a średni areał wzrósł z 4,3 do 7,2 ha. Mniejsza skala zmian była we Francji i Belgii, ale należy pamiętać że w tych krajach powierzchnia uprawy i zbiory ziemniaków były wyższe w końcu analizowanego okresu. W 2013 r. uprawą ziemniaków w tych krajach zajmowało się odpowiednio 22730 rolników ze średnim areałem 7,3 ha (Francja) i 11270 rolników ze średnim areałem 6,5 ha (Belgia).

Najbardziej spektakularny był spadek liczby producentów ziemniaków w Polsce, których liczbę w 2013 r. szacowano na ponad 510 tys. podczas, gdy w 2005 r. było to 1374 tys., a średni areał uprawianych ziemniaków w gospodarstwie wzrósł do 0,66 ha, wobec 0,43 na początku analizowanego okresu. Jeszcze większą ilość producentów i mniejszym

${ }^{2}$ Ostatnie dane Eurostat na o strukturze gospodarstw dotyczą 2013 r. 
średnim areałem charakteryzuje się uprawa ziemniaków w Rumunii. W tym kraju w $2013 \mathrm{r}$. jeszcze ponad 714 tys. rolników uprawiało ziemniaki w swoich gospodarstwach, a średni ich areał wynosił 0,16 ha i był nawet mniejszy niż 2005 r. (0,22 ha).

Na ogól, o wysokości plonów ziemniaków decyduje żyzność i warunki glebowe, ilość opadów atmosferycznych i dostęp do irygacji, promieniowania słonecznego, itp. (Pedersen S. M. i inni 2005). Jednak jak wynika z porównania wielkości średniego areału uprawy, ilości producentów oraz wysokości plonów koncentracji uprawy i wysokości plonów w Rumunii i w Polsce z tymi parametrami w Europie Zachodniej, to nasuwa się wniosek, że istotną, a być może nawet kluczową rolę odgrywa koncentracja i związana $\mathrm{z}$ tym intensywność uprawy. Dokładniejszy obraz ewolucji produkcji w wybranych krajach UE przybliża porównanie powierzchni uprawy ziemniaków według grup obszarowych z w uwzględnieniem zmian w perspektywie czasowej (2005 i 2013 r.)

Tabela 2. Powierzchnia uprawy ziemniaków według grup obszarowych w wybranych krajach UE w 2005 r.

Table 2. Area and number of potato producers in chosen EU countries in 2005

\begin{tabular}{|c|c|c|c|c|c|c|}
\hline Wyszczególnienie & Ogółem & do 1,9 ha & $2,0-4,9$ & $5,0-9,9$ & $10,0-19,9$ & pow. 20 ha \\
\hline & \multicolumn{6}{|c|}{ w tys. ha } \\
\hline Niemcy & 276,9 & 13,0 & 13,9 & 25,1 & 50,5 & 174,4 \\
\hline Francja & 154,6 & 6,6 & 6,4 & 17,9 & 38,4 & 85,4 \\
\hline Holandia & 155,8 & 1,0 & 6,6 & 17,8 & 35,7 & 94,8 \\
\hline Belgia & 65,0 & 3,0 & 11,5 & 17,3 & 17,2 & 16,0 \\
\hline Wlk. Brytania & 137,2 & 1,9 & 5,4 & 16,2 & 32,2 & 81,5 \\
\hline Polska & 588,2 & 433,7 & 70,6 & 29,1 & 23,9 & 30,9 \\
\hline \multirow[t]{2}{*}{ Rumunia } & 250,6 & 216,3 & 14,0 & 4,7 & 3,2 & 12,4 \\
\hline & \multicolumn{6}{|c|}{ w \% } \\
\hline Niemcy & 100,0 & 4,7 & 5,0 & 9,1 & 18,2 & 63,0 \\
\hline Francja & 100,0 & 4,2 & 4,1 & 11,6 & 24,8 & 55,3 \\
\hline Holandia & 100,0 & 0,6 & 4,2 & 11,4 & 22,9 & 60,8 \\
\hline Belgia & 100,0 & 4,6 & 17,7 & 26,6 & 26,4 & 24,7 \\
\hline Wlk. Brytania & 100,0 & 1,4 & 3,9 & 11,8 & 23,5 & 59,4 \\
\hline Polska & 100,0 & 73,7 & 12,0 & 4,9 & 4,1 & 5,2 \\
\hline Rumunia & 100,0 & 86,3 & 5,6 & 1,9 & 1,3 & 5,0 \\
\hline
\end{tabular}

Źródło: http://ec.europa.eu/eurostat/data/database, dostęp 10.06.2017, obliczenia własne.

Z danych zawartych w tabeli 2 wynika, że w Niemczech, Francji, Holandii i Wielkiej Brytanii 55-63\% powierzchni uprawianych ziemniaków znajdowało się w gospodarstwach, ze średnim areałem powyżej 20 ha, a plantacje mniejsze do 5 ha stanowiły zaledwie $5-10 \%$ areału ich uprawy ogółem. Nieco wyższe były te wskaźniki w przypadku Belgii. Natomiast w Polsce i w Rumunii duże plantacje (powyżej 20 ha) to było zaledwie 5\% upraw. Plantacje do 5 ha obejmowały w Polsce w prawie $86 \%$ areału, w tym do 2 ha $74 \%$ uprawianych ziemniaków ogółem. W Rumunii te wskaźniki wyniosły odpowiednio: 91,9 i 86,3\%.

Na przestrzeni ośmiu lat (2005-2013) udział plantacji największych (powyżej 20 ha) wzrósł we Francji, Holandii, Wlk. Brytanii i Niemczech do 58-71\%, a najmniejszych do 5 ha obniżył się do 3-8\%.Zmiany w tym zakresie w Belgii były nieznaczne. Natomiast w Polsce różnice w koncentracji uprawy ziemniaków są jednoznacznie zauważalne: w największych plantacjach (powyżej 10 ha) znajdowało się 25,3\% areału uprawy ziemniaków ogółem $(9,3 \%$ 
w 2005 r.), a plantacje najmniejsze do 2 ha obejmowały $60,8 \%$ areału, wobec $85,7 \% \mathrm{w}$ 2005 r. W Rumunii praktycznie nie zaobserwowano w tym zakresie żadnych zmian (tab. 3).

Tabela 3. Powierzchnia uprawy ziemniaków według grup obszarowych w wybranych krajach UE w 2013 r. Table 3. Area and number of potato producers in chosen EU countries in 2013

\begin{tabular}{l|rrrrrr}
\hline \multicolumn{1}{c|}{ Wyszczególnienie } & Ogółem & do 1,9 ha & $2,0-4,9$ & $5,0-9,9$ & $10,0-19,9$ & pow. 20 ha \\
\hline \multirow{2}{*}{ Niemcy } & \multicolumn{5}{c}{ w tys. ha } \\
Francja & 242,8 & 6,7 & 9,8 & 18,2 & 35,3 & 172,9 \\
Holandia & 166,6 & 6,1 & 6,8 & 18,3 & 38,4 & 97,0 \\
Belgia & 155,8 & 0,8 & 5,8 & 15,9 & 30,0 & 103,4 \\
Wlk. Brytania & 73,1 & 2,5 & 12,0 & 19,9 & 21,2 & 17,4 \\
Polska & 139,7 & 1,1 & 3,3 & 12,0 & 28,3 & 94,8 \\
Rumunia & 337,0 & 155,5 & 49,5 & 43,2 & 36,2 & 52,7 \\
& 111,5 & 93,1 & 6,4 & 3,5 & 2,4 & 6,1 \\
Niemcy & & & & & \\
Francja & 100,0 & 2,7 & 4,0 & 7,5 & 14,6 & 71,2 \\
Holandia & 100,0 & 3,6 & 4,1 & 11,0 & 23,1 & 58,2 \\
Belgia & 100,0 & 0,5 & 3,7 & 10,2 & 19,3 & 66,3 \\
Wlk. Brytania & 100,0 & 3,5 & 16,4 & 27,2 & 29,0 & 23,8 \\
Polska & 100,0 & 0,8 & 2,4 & 8,6 & 20,3 & 67,9 \\
Rumunia & 100,0 & 46,1 & 14,7 & 12,8 & 10,7 & 15,6 \\
\hline
\end{tabular}

Źródło: http://ec.europa.eu/eurostat/data/database, dostęp 10.06.2017, obliczenia własne.

Analizując zmiany ewolucji produkcji ziemniaków w poszczególnych krajach UE można dojść do wniosku, że jej skalę wyznaczają potrzeby rynku (Nowacki 2012, 2015). W sytuacji gdy zapotrzebowanie rynku (szeroko rozumiane jako konsumpcja rynkowa i samozaopatrzenie, przetwórstwo przemysłowe oraz eksport ziemniaków i ich przetworów) nie rośnie lub rośnie w sposób niewystarczający, przy malejącym, pozarynkowym (paszowym) wykorzystaniem ziemniaków, mamy do czynienia ze spadkiem produkcji ziemniaków.

W celu potwierdzenia tezy dokonano analizy porównawczej bilansu ziemniaków w Polsce i w Niemczech. Ze względu na duże wahania produkcji ziemniaków w poszczególnych latach, powodowanych głównie warunkami pogodowymi (duża zmienność plonów), wydzielono kilka okresów badawczych i policzono dla nich średnie wartości dla poszczególnych pozycji bilansu (tab. 4). Z kalkulacji tych wynika, że produkcja ziemniaków w Polsce (zbiory pomniejszone o ubytki i straty) w latach 2012-2015 wynosiła średnio 7,0 mln, wobec $15,8 \mathrm{mln}$ ton średnio w latach 2000-2003, co stanowiło spadek o około $56 \%$.W tym okresie rynkowe wykorzystanie ziemniaków (konsumpcja, zużycie przemysłowe, eksport) zmalało o ok. $1 \mathrm{mln}$ ton (z 6,43 do $5,48 \mathrm{mln}$ ton), tj. o $15 \%$. Jednocześnie nastąpiło ograniczenie paszowego wykorzystania ziemniaków z 7,28 do $1,15 \mathrm{mln}$ ton, tj. o ponad $84 \%$. Zmniejszenie wykorzystania sadzeniaków ziemniaków na reprodukcję (z 2,13 do $0,77 \mathrm{mln}$ ton) było konsekwencją spadku areału ich uprawy. Jedyną rosnąca pozycją w polskim bilansie był wzrost eksportu, przy czym dotyczył on przede wszystkim przetworów ziemniaczanych, gdyż sprzedaż na rynki zagraniczne ziemniaków świeżych jest marginalna, głównie ze względu na występującą w Polsce bakteriozę pierścieniową ziemniaka (Chotkowski, Rembeza, 2013). 
Tabela 4. Bilans ziemniaków w Polsce i w Niemczech (tys. ton)

Table 4. Potato balance sheet in Poland and Germany ('000 tons)

\begin{tabular}{|c|c|c|c|c|}
\hline Wyszczególnienie & $\begin{array}{c}2000 / 01- \\
2003 / 04\end{array}$ & $\begin{array}{c}2004 / 05- \\
2007 / 08\end{array}$ & $\begin{array}{c}2008 / 09- \\
2011 / 12\end{array}$ & $\begin{array}{c}2012 / 13- \\
2015 / 16\end{array}$ \\
\hline & \multicolumn{4}{|c|}{ Polska } \\
\hline Produkcja* & 15785 & 10203 & 8662 & 7004 \\
\hline Import** & 58 & 245 & 359 & 391 \\
\hline Zasoby & 15843 & 10448 & 9021 & 7395 \\
\hline Eksport** & 412 & 416 & 534 & 729 \\
\hline Sadzenie & 2134 & 1448 & 1055 & 772 \\
\hline Konsumpcja & 5025 & 4735 & 4365 & 3971 \\
\hline Zużycie przemysłowe & 998 & 731 & 645 & 776 \\
\hline \multirow[t]{2}{*}{ Zużycie paszowe } & 7276 & 3118 & 2421 & 1146 \\
\hline & \multicolumn{4}{|c|}{ Niemcy } \\
\hline Produkcja* & 10509 & 10612 & 10590 & 9890 \\
\hline Import** & 1515 & 1623 & 1858 & 1957 \\
\hline Zasoby & 12024 & 12235 & 12447 & 11847 \\
\hline Eksport** & 2246 & 2715 & 3147 & 3704 \\
\hline Sadzenie & 665 & 641 & 576 & 538 \\
\hline Konsumpcja & 5612 & 5307 & 5060 & 4572 \\
\hline Zużycie przemysłowe ${ }^{* * *}$ & 2954 & 2881 & 2875 & 2208 \\
\hline Zużycie paszowe & 548 & 691 & 790 & 824 \\
\hline
\end{tabular}

*produkcja pomniejszona o ubytki i straty, **eksport i import ziemniaków i ich przetworów w ekwiwalencie ziemniaków, ***dotyczy przerobu na skrobię oraz na spirytus.

Źródło: obliczenia własne na podstawie danych GUS, ZMP i AMI.

W analizowanym okresie produkcja ziemniaków w Niemczech zmniejszyła się o niepełna $6 \%$, a zasoby (produkcja + import) o 1,5\%. Rynkowe wykorzystanie ziemniaków w tym kraju zmalało o ok. $0,3 \mathrm{mln}$ ton (z 10,8 do $10,5 \mathrm{mln}$ ton), tj. o $3 \%$, przy czym konsumpcja ziemniaków zmniejszyła się z 5,6 do 4,6 mln ton, przemysłowe wykorzystanie ziemniaków (na skrobię i spirytus) spadło z 3,0 do 2,2 mln ton, jedynie znacząco wzrósł eksport (z 2,2 do 3,7 mln ton). W niemieckim eksporcie, w odróżnieniu od Polski, mniej więcej po 50\% stanowią ziemniaki do bezpośredniej konsumpcji i przetwory ziemniaczane. Wykorzystanie paszowe ziemniaków w Niemczech w całym analizowanym okresie było bardzo niskie i w poszczególnych latach wahało się od kilkudziesięciu do miliona ton rocznie, średnio $0,55 \mathrm{mln}$ ton $\mathrm{w}$ latach 2000/01-2003/04 i $0,82 \mathrm{mln}$ ton $\mathrm{w}$ latach 2012/13-2015/16. Na pasze w Europie Zachodniej już od wielu lat na pasze przeznacza się bulwy, które nie mogą być w inny sposób zagospodarowane (tzw. plon odpadowy $\mathrm{w}$ gospodarstwie), natomiast w Polsce do tego standardu powoli dochodzimy dopiero w ostatnich latach. W analizie porównawczej bilansu ziemniaków w Polsce i w Niemczech zwraca uwagę podobna skala spadku konsumpcji ziemniaków, ale jej poziom jest nieporównywalny. Otóż w Polsce bilansowe spożycie ziemniaków (nieprzetworzonych i ich przetworów) wynosi w ostatnich latach ok. $100 \mathrm{~kg} /$ mieszkańca (GUS, 2016), natomiast w Niemczech nieznacznie przekracza 50 kg/mieszkańca (Markt Bilanz, 2016). 


\section{Podsumowanie}

Przeprowadzona analiza zmian produkcji ziemniaków w latach 2000-2016 potwierdziła dynamiczny ich przebieg w Polsce oraz niższą dynamikę w krajach UE. Spadkowi zapotrzebowania na ziemniaki (głównie paszowego) w Polsce towarzyszyło gwałtowne zmniejszenie areału, który częściowo został zrekompensowany wzrostem plonów. Zmiany w produkcji ziemniaków dotyczą również wiodących producentów w Europie Zachodniej. W większości krajów również ma miejsce ograniczeniu areału uprawy, wzrost plonów i relatywnie niewielki spadek zbiorów, ale skala tych zmian jest nieporównywalnie mniejsza niż w Polsce. Jedynie we Francji i Belgii, z powodu wzrostu zapotrzebowania eksportowego (we Francji na ziemniaki konsumpcyjne, a w Belgii na przetwory), zwiększył się areał uprawy i produkcja ziemniaków w tych krajach.

Bez względu na skalę zmian produkcji ziemniaków we wszystkich krajach UE postępują procesy koncentracji ich uprawy. Mimo postępujących procesów koncentracji W uprawie ziemniaków w Polsce, ich przeciętny areał $(0,66$ ha) jest nieporównywalnie mniejszy niż w Europie Zachodniej (6,5-7,3 ha średnio w Belgii, Francji i Niemczech i 16,9-17,0 ha w Holandii i Wlk. Brytanii), ale wyraźnie większy niż w Rumunii (0,16 ha). Konsekwencją dużego rozdrobnienia uprawy i produkcji jest znacząco niższy poziom plonów ziemniaków w Polsce w porównaniu z krajami Europy Zachodniej, chociaż dysproporcje te na przestrzeni analizowanego okresu wyraźnie się zmniejszyły.

\section{Literatura}

Chotkowski, J., Rembeza, J. (2013). Bakterioza pierścieniowa ziemniaka jako choroba kwarantannowa uzasadniona ostrożność czy forma protekcji handlowej. Roczniki Naukowe SERIA, 15(1), 12-17.

Commission of the European Communities 2007. The potato sector in the European Union. phttps:/ec.europa.eu/agriculture/sites/agriculture/files/publi/reports/fruitveg/potato/sec533 en.pdf, Brussels

Dzwonkowski, W. (2002). Uwarunkowania eksportu ziemniaków i ich przetworów w „Ekonomika i technologia produkcji ziemniaków jadalnych. W: Produkcja i rynek ziemniaków jadalnych. Praca zbiorowa pod redakcją J. Chotkowskiego, Wieś Jutra. Warszawa, 7-20.

Dzwonkowski, W. (2012). Międzynarodowy rynek a eksport ziemniaków z Polski. W: Produkcja i rynek ziemniaka. Praca zbiorowa pod redakcją J. Chotkowskiego, Wieś Jutra. Warszawa, 29-39.

Dzwonkowski, W. (red.). (2016). Rynek Ziemniaka. Stan i perspektywy. Analizy Rynkowe nr 43, Warszawa, MRiRW, ARR, IERiGŻ-PIB.

Eurostat (2017). Pobrano 14 czerwca 2017 z: http://appsso.eurostat.ec.europa.eu/nui/show.do?dataset=apro_ acs_a\&lang=en.

GUS (2017). Wyniki produkcji roślinnej w 2016 r., Warszawa.

GUS (2016). Dostawy na rynek krajowy oraz spożycie niektórych artykułów konsumpcyjnych na 1 mieszkańca w 2015 r, Opracowanie sygnalne, Warszawa.

Infante, R.R (2008). La pomne de terredans la chainealimentare - materiał prezentowany podczas spotkania eksperckiej grupy roboczej ForecastWorkingGroup of Potato, Bruksela.

Kartoffeln Markt Billanz (2010). (ZMP) Zentrale Markt-und Preisberichstelle GmbH, Bonn.

Markt Bilanz Kartoffeln 2016/17 (2016). (AMI) Agramarkt Informations-Gesselschaft mbH, Bonn.

Nowacki W. (2015) Szanse i zagrożenia rynku ziemniaków w Polsce. Roczniki Naukowe SERIA, 17(3), 169-175.

Nowacki, W. (2012). O kierunkach zmian w uprawie ziemniaka w Polsce. Biuletyn Instytutu Hodowli i Aklimatyzacji Roślin, 266, 21-35.

Pedersen, S.M., Bizik, J., Costa, L.D., Coutinho, J., Dolezal, F., Gluska, A. (2005). Potato production in Europe a gross margin analysis. (FOI Working Paper; No. 5, Vol. 2005. Uuniversity of Copenhagen.

Potato Market and Trade Review (2017). Agri Markets Ltd, Kent.

Rembeza, J. (1995). Produkcja i rynek ziemniaków krajach europejskich. Instytut Ziemniaka, Bonin.

Rembeza, J. (2002). Rynek ziemniaków jadalnych w Europie i na świecie. W: Produkcja i rynek ziemniaków jadalnych. Praca zbiorowa pod redakcją J. Chotkowskiego, Wieś Jutra. Warszawa,7-15. 